\title{
A brief history of the sand drifts on the Jaren coast, Norway
}

\author{
A. Tørum ${ }^{1} \&$ O. T. Gudmestad ${ }^{2}$ \\ ${ }^{I}$ Norwegian University of Science and Technology, Department of \\ Civil and Transport Engineering, NTNU, Trondheim, Norway \\ ${ }^{2}$ University of Stavanger, Stavanger, Norway
}

\begin{abstract}
The Norwegian coastline is mainly rocky with no major problems related to beach erosion and littoral drift. However, the Jæren coastline has some stretches of sandy beaches. The Jæren coast is facing the North Sea with severe wave conditions. The highest recorded storm surge level is $1.2 \mathrm{~m}$ above mean sea level. The water level in the area has been varying and was 4000 years ago approximately $5 \mathrm{~m}$ higher than it is today. Since then, the water level has steadily decreased until today's level. There are no big rivers entering the sea at the Jæren coast. The beaches were formed primarily by the moving ice during the glacial periods. Excavations have revealed approximately 2500 year old farm fields, which later have been covered by thick Aeolian sand. The beaches do not erode significantly today. The sand on these beaches has historically been a nuisance to the farmers in the area when the wind has blown the sand into the farm fields. In 1806, the Danish-Norwegian government sent Captain Knop to survey the area. He made maps of the coastline and plans to plant marram grass to stop the Aeolian sand drift. However, as Norway became part of Sweden in 1814, the Swedish-Norwegian government did not follow up the plans to plant marram grass. The wind blowing sand conditions were especially bad around 1870 . The high windy conditions have been revealed by wind observations in the area since 1865. It was then decided to plant marram grass, which has been a success to stop the sand from blowing into the farm fields. The paper discusses the evidence of sand dune growth on the Jæren coast and the reasons why there has been no significant long term beach erosion in the area.

Keywords: beach erosion, sand drift, marram grass, growth of sand dunes.
\end{abstract}




\section{Introduction}

The Jæren coastline south of the city of Stavanger on the south-western tip of Norway (Figure 1) has some stretches of beaches. Figure 2 shows the beach north of Revtangen. The beach and dunes consist of fine sand, gravel and even in some cases cobbles. We should note The South Norwegian Deep Channel (Figure 1) that runs along the south coast of Norway is some $300 \mathrm{~m}$ deep and has been "carved" out by glaciers. The Lista stage end moraine running along the coast is an end moraine left by glaciers. Note that the bottom slope is mild close to the coast, but very steep into the South Norwegian Deep Channel.

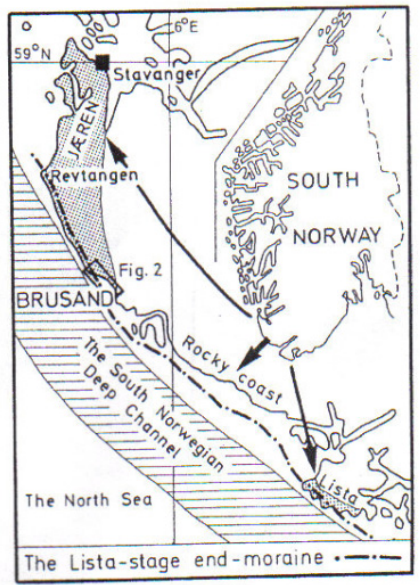

Figure 1: $\quad$ The location of Jæren at the south-west tip of Norway [1].

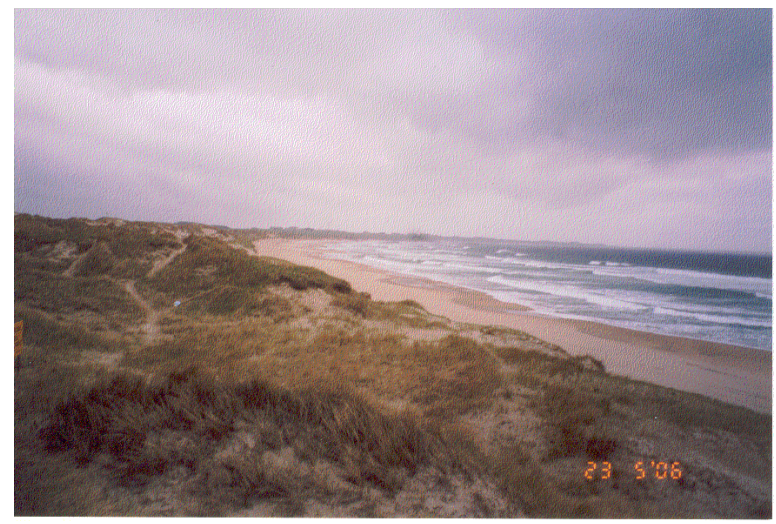

Figure 2: $\quad$ The beach and dunes at Bore-Sele seen towards Revtangen in 2006. 
There are no big rivers entering the sea at Jæren. The sand, gravel and boulders on the sea bottom, on the beaches and on land have been brought there by glaciers during the last glaciations, e.g. in the time period 29,000-15,000 years ago. There is hardly any investigation on the magnitude of sand-gravelboulders that is located on the beaches and in the sea outside Jæren. However, a drilling was made in 1993 close to the sea level at Grødaland, somewhat south of Revtangen (Figure 1) [2]. The drill-bit reached to a depth of $123 \mathrm{~m}$ before it stopped on solid rock. The drill core contained clay, sand, gravel and some coarser material. Paper [3] refers to several tenths of meters thick layers of moraine material along a cross section south of Revtangen. It is thus obvious that large quantities of moraine material are available outside the coast of and on land at Jæren. The farmers at Reve have previously taken sand and gravel from the beach for use on their farms (for roads, ditches and concrete).

\section{Soil investigations on Jæren}

The beaches along the Jæren coast are apparently fairly stable with only some minor setbacks during heavy storms (Figure 3). This setback is apparently temporary as the dunes grow again.

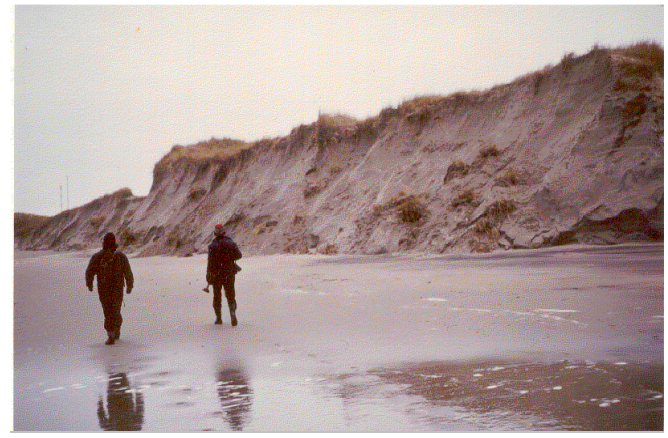

Figure 3: The sand dunes at Bore-Sele (Figure 2) seen two days after a heavy storm in November 1981. There has in this case been considerable erosion of the beach and the dunes. The dune height is estimated to be $6-8 \mathrm{~m} \mathrm{[4].}$

We will explore this apparent beach and dune long term evolvement later. But first we will give an account of the aeolian sand drift in the Jæren area, a drift that has been a nuisance to the farmers in the area, but which is now brought under control, mainly by planting marram grass (Ammophila areanana).

A soil section from excavations at the Stavanger airport Sola shows a peat layer. The peat layer varies in thickness and reaches up to $80 \mathrm{~cm}$ in thickness. The bottom of the peat layer is $\mathrm{C}^{14}$ dated to be from $4540 \pm 90$ years before present (BP). The upper part of the peat layer "6" was dated to $2540 \pm 80$ years BP. The layer above is Aeolian sand (wind driven sand). While removing some of the peat layer a series of tilled grooves were observed. They penetrated the 
peat layer and were interpreted as plough marks, reflecting cultivation dated to the time interval 2550-2200 years BP [5]. Pollen analysis from seven places in layer indicates also that the land has been cultivated. There has been a discussion why the peat was later covered by the Aeolian sand layer. Paper [5] indicates that the soil through farming was exploited, the rather thin soil layer to some extent disappeared and the sand layers were "attacked" by the wind. However, this may not necessarily be true. Nature itself has also contributed to this sand covering, which will be discussed later in this paper.

\section{Waves, currents and water levels on the Jæren coast}

The Jæren coast is facing the North Sea where there are severe wave conditions from time to time. The wave conditions have been investigated for the recently built breakwater at Sirevåg on the southern part of Jæren, close to Brusand (Figure 1). The 100-year design wave conditions for the Sirevåg breakwater at $17 \mathrm{~m}$ water depth is a significant wave height $\mathrm{H}_{\mathrm{s}, 100}=7.0 \mathrm{~m}$, and a mean wave period $\mathrm{T}_{z, 100}=10.6 \mathrm{~s}$ [6]. This estimate was made from wave hindcast by the Norwegian Meteorological Institute and by refraction analysis. During heavy storms in 2002 and 2005 the waves were close to the 100 -year return period level. The Norwegian Coastal Current runs along the coast of Jæren. The current velocity is highest northwards and may reach values up to approximately $0.3 \mathrm{~m} / \mathrm{s}$. The tidal variation is small along the Jæren coast. Storm surges have larger impacts on the water level than the astronomical impact. The highest observed water level in Stavanger is $+1.84 \mathrm{~m}$ above Chart Datum, which is $0.20 \mathrm{~m}$ below Lowest Astronomical Tide (LAT). The highest astronomical tide is at $+1.11 \mathrm{~m}$ above Chart datum. The mean sea level, MSL, is at $+0.65 \mathrm{~m}$ above Chart Datum. Paper [7] investigated the simultaneous occurrence of water levels in Stavanger, where the Norwegian Mapping Authority has a permanent tide gauge station, and the significant wave heights in two grid points in deep water outside the Jæren coast for the time period 1979-1997. The results of the investigations by [7] show a trend that there are high water levels when there are high waves. The Scandinavian Peninsula was covered with an ice sheet of about 3-4000 $\mathrm{m}$ thickness during the last ice age. The land was pressed down and the relative water level was much higher than today. The Jæren area has been emerging during the last 4000 years. This may explain why the beaches have not had serious set-backs during resent time. Later we will show evidence that sand dunes in the Jæren area have grown significantly during the last 100 years after marram grass was planted.

\section{Jæren as farmland}

Today the Jæren area is among the best farmland in Norway (Figure 4), but it has not always been the case. The area was much hampered by sand drift during heavy storms. Sand drifts forced the farmers to abandon their farms. Figure 5 shows a map from 1806 [8] of the same area shown in Figure 4. The farms are located among sand ridges/dunes. 


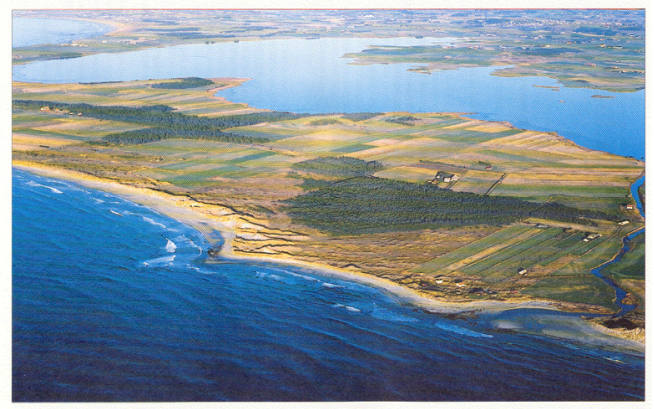

Figure 4: $\quad$ Orre in Klepp commune slightly south of Revtangen (Figure 1). (Courtesy Norsk fly and Flyfoto A/S, Rogaland county Governor (1995).)

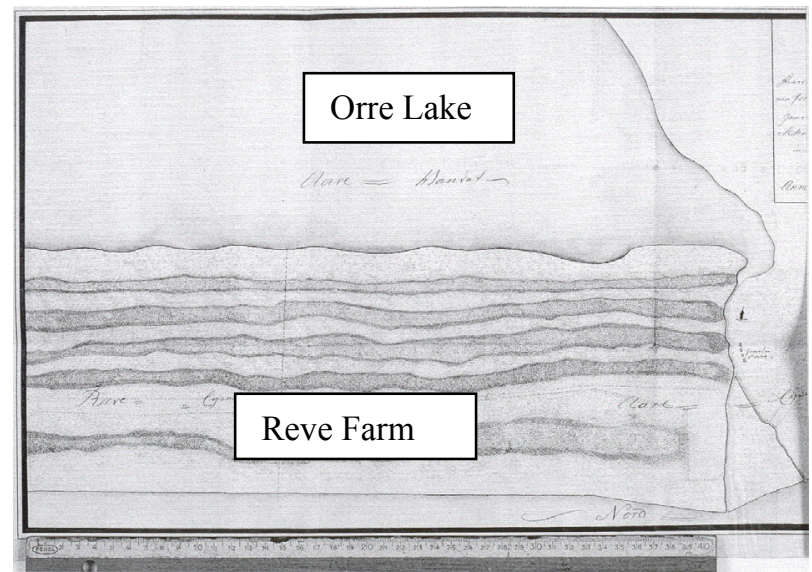

Figure 5: $\quad$ Orre Lake with the Reve Farm. Map of the planned $4^{\text {th }}$ sand drift district on Jæren [8]. (Courtesy national archives of Norway, Oslo.)

Paper [9] writes about the transformation from wealth to poverty for the tree farms at Orre, Reve and Vik at the end of the $17^{\text {th }}$ century. The farmers asked for reduced taxes and land rental. Because of the long term strong north-western winds at that time sand was blown into the farm fields, destroying or reducing them for the purpose of farming. Some of the farms were even abandoned. The sand drift was caused, as mentioned, by the strong north-western winds, while farming itself might have damaged the vegetation such that the wind could more easily access the sand. Norway was at that time part of the Danish kingdom. Marram grass had to some extent been used in Denmark by that time to dampen sand drift. The authorities in Copenhagen sent captain Knoph to survey the Jæren coast and draw up plans to combat sand drift by planting marram grass [8]. The Danish prime minister visited Stavanger in 1811. The newspaper Stavanger 
Aftenblad reports in the issue of 3 December 1955 from his diary when he visited the Jæren coastline from which he gave an account on the damaging sand drift.

Norway used the opportunity after the Napoleonic wars to get their own constitution and their own parliament in 1814 , but had to accept that the Swedish king became King of Norway until 1905, when Norway became an independent kingdom. Norway was not a rich country in 1814 . Hence there was no focus from the Norwegian authorities to improve the conditions for the farmers on Jæren. The sand drift was, however, attempted to be stopped by wooden fences (Figure 6) [10]. These sand fences were apparently not extensively used and may have proven costly and not very effective in reducing the sand drift. It was not until approximately 1870 that the issue of improving the conditions for the farmers on Jæren again was raised. By that time the long term north-western wind started again with sand drifts into the farm fields [11].

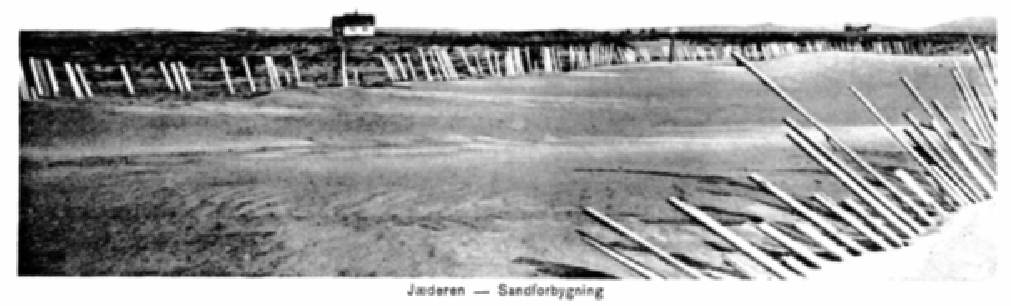

Figure 6: Attempt to stop sand drifts on Jæren by wooden fences [10].

The Norwegian author Arne Garborg [12] reminisces when he, together with his father, as a 7 year old boy visited the farm of Torger Nærland in the late 1860s. The Nærland farm was located about one km from the sea. Garborg saw then the large sand dunes, sand dunes that also covered farm land. During heavy winds the sand drifts reminded him of heavy snow storms and the sand drift blocked even the entrance doors. Heavy northern storms occurred in the late 1860s. This is verified by the information given in Figure 7, showing the number of storm days at Utsira during the time period 1860-1988 [13]. Utsira is an island some $65 \mathrm{~km}$ north-west of the city of Stavanger (Figure 1). Later on, when Arne Garborg visited the Nærland farm in the 1890s, he reported, again in "Letters of Knudahei", that where there had been sand dunes and sand drifts, there was now fertile farm fields and even fruit and berry gardens. So what had happened?

The most important tool in the battle against the sand drifts was the planting of marram grass. A pioneer in this work was Torger Nærland [11]. Nærland contacted in about 1870 the local pastor, who advised him to write to the county governor. He again sent Martin Grude, the District Sheriff and teacher of a local agricultural school, to Denmark to study the use of marram grass to damp the sand drift. So gradually the sand ridden land was made into fertile land as it can be seen in Figure 4. 


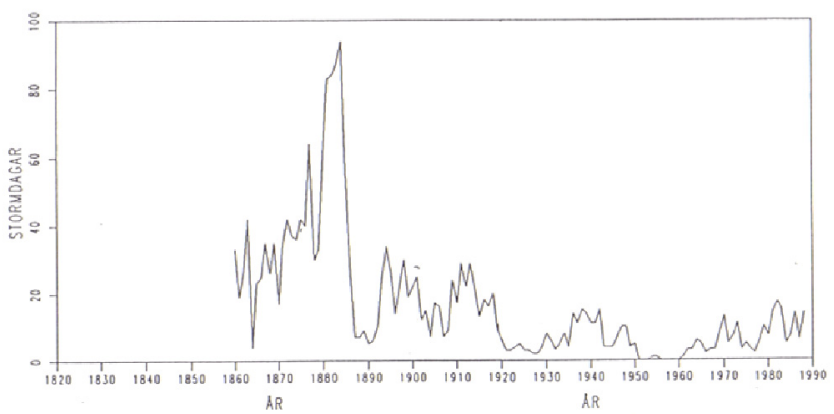

Figure 7: Number of storm days at Utsira lighthouse in the time period $1860-1988$ [13].

\section{The beaches and sand dunes at Bore-Sele, Reve and Brusanden}

As evidence of the positive effect of the marram grass we give a brief account of the beaches and sand dunes at Bore-Sele, Reve and Brusanden (Figure 1).

\subsection{Bore-Sele}

Since 1965 the dunes have progressed some 100-150 $\mathrm{m}$ towards the sea. This is due to the marram grass, which covers the dunes. The marram grass requires that new sand is brought in from the sea since the marram grass is dependent on nutritious elements being brought in with the sand from the sea. The diameter of the sand brought in by the wind is approximately $\mathrm{d}_{50}=0.20 \mathrm{~mm}$.

\subsection{Reve}

Another place where the sand dunes have grown significantly in the latter 100 years is at Reve and Revtangen (Figure 1). At about 1870 a sailing mark was erected at Reve to help ships with their navigation during day time ("Day-time marker", no lights). Figure 8 shows an older painting from the Reve area where the "Day-time marker" is visible. Many ships went aground on the Jæren coast and whenever this happened there was an auction of the ship wrecks. The painting shows that the area at Revtangen at the end of the $19^{\text {th }}$ century was rather flat. The forester Jacob Bøckmann Barth was bird hunting on Reve in 1875. He wrote (in Norwegian) an account of the landscape from one of his hunting trips at Reve: "I went from the Reve farms towards the shore plain. Then I saw a very flat area, only some few feet above the sea level. The area was approximately $4 \mathrm{~km}^{2}$ and was covered with wind-driven sand. The desert like area was impressive without any plants or animals. The only sight catching item was the "Day-time marker"". 


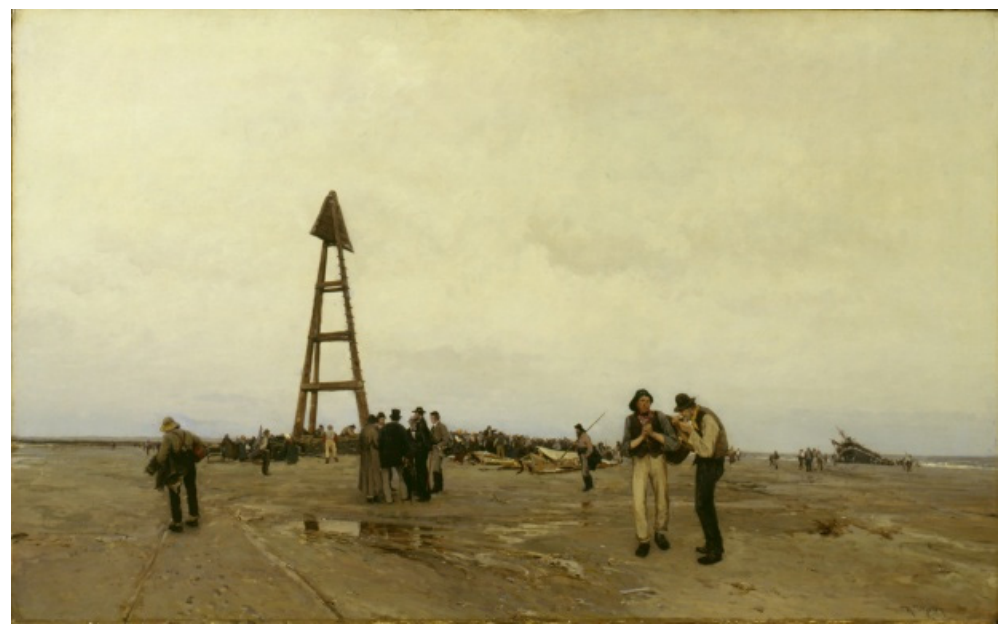

Figure 8: Ship wreck auction under the "Day-time marker" at Revtangen. Painting by Nicolai Ulfsten, 1880. (Courtesy O. Værings Eftf. AS.)

The "Day-time marker" was abandoned when new modern navigation became available in the beginning of the $20^{\text {th }}$ century. It was, however, decided in 2004 to restore the "Day-time marker" as a cultural heritage. The old concrete foundations were unburied to be used for the new "Day-time marker". Figure 9 is a photograph from the un-burying of the old foundations. The sand dunes are several meters high. The highest dunes today at Reve are approximately $7.5 \mathrm{~m}$ above sea level.

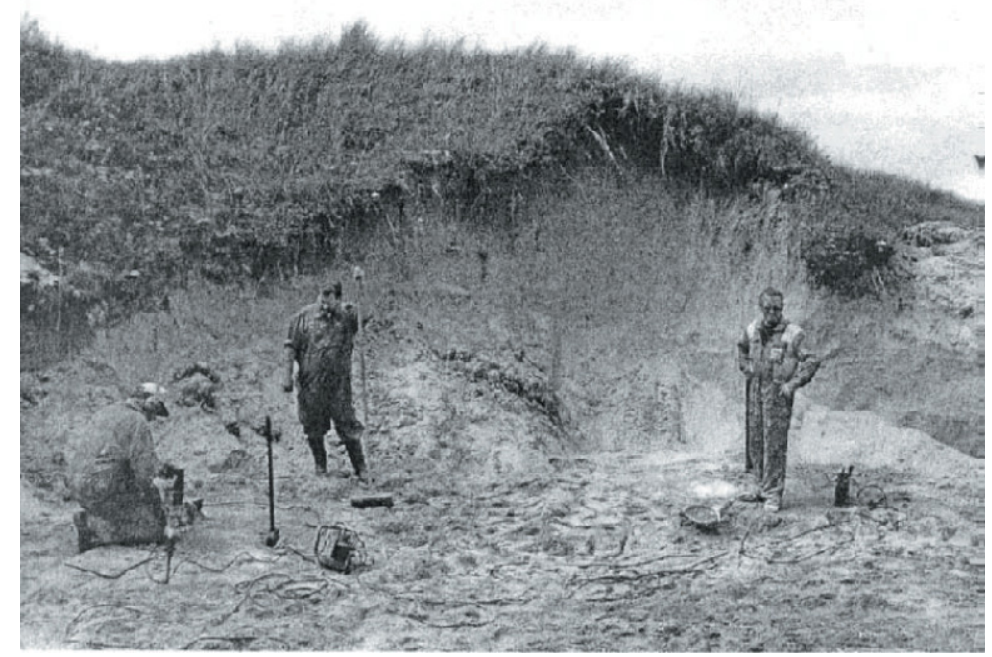

Figure 9: Uncovering of the old concrete foundations for the "Day-time marker" at Reve in 2004. (Photograph and information by Thore Refve, Reve Jæren.) 


\subsection{Brusanden}

Brusanden is located in the southern end of Jæren (Figure 1). Figure 10 shows a photograph of the area in 1963. It shows that there is hardly any vegetation between the small creek and the ocean.

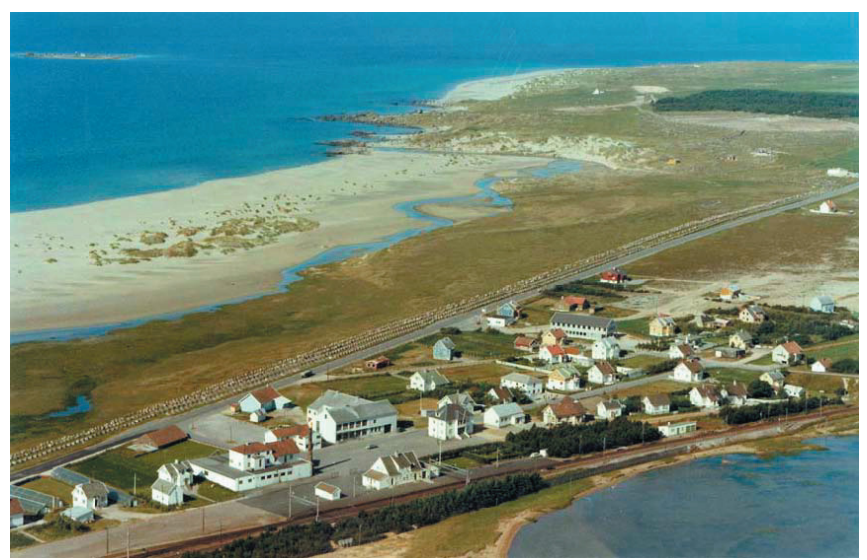

Figure 10: $\quad$ Brusand 1963. (Photo: Fjellanger Widerø A/S.)

Figure 11 shows the northern end of Brusanden in 2007. Marram grass was planted on Brusanden in 1894. But this planting was not successful. Later marram grass was planted on Kvalbeinsanden slightly north of Brusanden. This planting was successful. By natural spreading the marram grass has also settled on Brusanden, which dunes have grown considerably during the last 40-50 years.

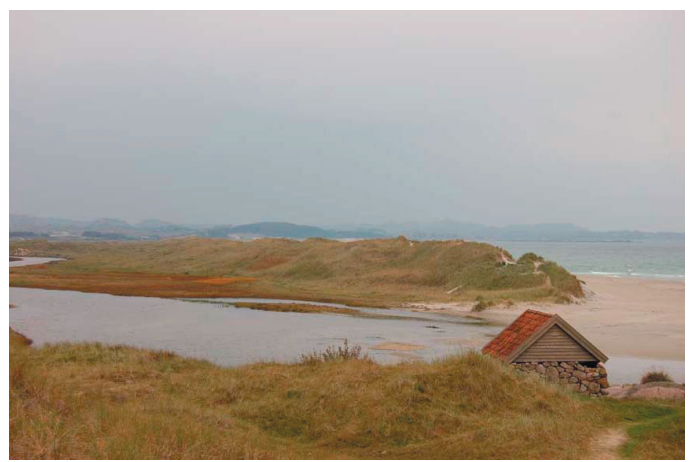

Figure 11: Northern end of Brusanden in 2007 with the outlet of the small river. 
Figure 12 shows a map from 1708 of the Brusanden area. The map indicates that Lake Waulen was then larger than it is today. In fact, Lake Waulen is today almost dry and a small river remains.

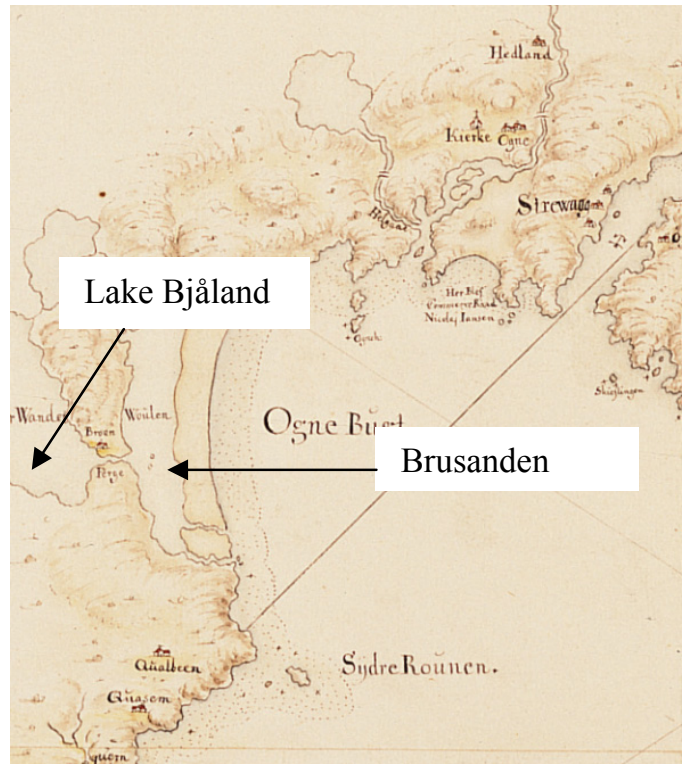

Figure 12: Section of antiquarian map by R. Juel of Jæren and Stavanger 1708-Ogne bugt. (Printed with permission from the Norwegian mapping authority.)

Paper [1] discusses changes of water levels between 1839 and 1939. They indicate a sea level fall of $7 \mathrm{~cm}$, but there are some uncertainties on this figure. However, the sea level was probably $10-20 \mathrm{~cm}$ higher in 1708 than it is today. The map of 1706 (Figure 12) was produced by the Danish Navy, which concentrated on the coastal area. The scale on land of the map from 1706 may thus vary. But as Lake Waulen is depicted on the maps it is reasonable that the lake was larger previously than it is today. This may be due to higher water levels, but it may also be due to sand drifts through the years which have caused the lake to be filled with sand as the lagoons at Lista, Reve, Bore-Selesanden and Solasanden [1].

\section{Kelp and its effects on beach and dune erosion}

Kelp (Laminaria hyperborean) is growing many places outside the Jæren coast. There is harvesting of kelp in the kelp fields outside the Jæren coast. The kelp is used for production of alginates. The harvesting is regulated. The kelp fields are divided into smaller areas and each area is harvested every 5 years. There has been some concern that the kelp harvesting increases beach and dune erosion. Papers $[14,15]$ conclude that this most probably is the case. It is true that kelp damps non-breaking waves significantly. However, in the surf zone the wave 
breaking process takes much more energy out of the waves than the kelp does. Hence, harvesting of kelp would not significantly affect beach and dune erosion.

\section{Possible explanation of the growth of the sand dunes on Jæren}

Beach erosion has apparently not been of any concern at the Jæren coast. However, wind drift of sand has been a nuisance to farmers in the area. It is a fact that the sand dunes at Bore-Sele, Reve and Brusanden have been growing during the last 50-100 years. The planting of marram grass has contributed significantly to this fact. But it also shows that there is transport of sand from the sea to the coast. Since there are no big rivers entering the sea at Jæren the sand must come from the offshore glacial deposits. According to the general knowledge we have about water levels and beach and dune erosion it is reasonable to assume that there is a transport from the sea to the beach and the dunes.

Paper [16] describes the Moruya Beach in Australia that has grown significantly during the last 6000 years. The sand in the sea was deposited during a glacial period. The Moruya Beach is a pocket beach and no sand has been transported into the area neither from rivers nor along the beach. The water level has not varied significantly during the last 6000 years. The rate of propagation of sand volume into the beach has been decreasing and is today approximately $4 \mathrm{~m}^{3} /$ year per $\mathrm{m}$ beach length.

As a comparison we have estimated that the rate of sand propagation into the dunes at Bore has been approximately $15 \mathrm{~m}^{3} /$ year per $\mathrm{m}$ beach length during the last 45 years. It is interesting to note that for the Moruya Bay, the sand has been brought up from approximately $50 \mathrm{~m}$ water depth. In this respect it should be noted that during heavy storms, sand at the Ekofisk oil field at $70 \mathrm{~m}$ water depth in the North Sea moves [17]. Hence sand and gravel from a considerable water depth outside the Jæren coast may be moved toward the coast. The beaches at Bore-Sele, Reve and Boresanden are a mixture of coarse and fine sand. The fines, $\mathrm{d}_{50} \approx 0.2 \mathrm{~mm}$, are to a large extent blown inland and are today caught by the marram grass, which leads to the build-up of the dunes. Thus the findings at Moruya Beach support the findings that the dunes at Jæren have grown during the last 100 years.

\section{References}

[1] Bird, E.C. and Klemsdal, T. (1986): Shore displacement and the origin of the lagoon at Brusand, South western Norway. Norsk geografisk tidsskrift, (The Norwegian Journal of Geography), Vol. 40, 27-35, Oslo.

[2] Sejrup, H.P., Iversen, M., Larsen, E., Landvik, J.Y. and Janocko, J. (1999): A stage 7 marine interglacial record (the Grødaland interglacial) on Jæren, south western Norway; foraminiferal, stable isotopes and amino acid evidence. Boreas, Vol. 28, pp. 326-346. Oslo.

[3] Larsen, E., Sejrup, H.P., Janocko, J., Landvik, J.Y., Stalsberg, K. and Steinsund, P.I. (2000): Recurrent interaction between the Norwegian 
Channel Ice Stream and terrestrial-based ice across southwest Norway. Boreas, Vol. 29, pp. 185-203. Oslo.

[4] Sjulsen, O.E. (1982): Sedimentologisk analyser og geomorfologisk kartlegging I kystnære deler av Sola og Kleppe kommuner på Jæren. Hovedfagsoppgave i geografi, Geografisk institutt, Universitetet i Oslo. In Norwegian. (Sedimetological analysis and geomorphological mapping in near coastal areas in the communities Sola and Kleppe on Jæren. Master thesis, Department of Geography, University of Oslo, Norway.

[5] Prøsch-Danielsen, L. (2006): Sea-level studies along the coast of south western Norway. With emphasis on three short-lived Holocene marine events. AmS-Skrifter 20. Museum of Archaeology, Stavanger. National research centre for paleostudies and conversation. Stavanger, Norway.

[6] Tørum, A., Løset, S. and Myhra, H. (2005): Reshaping of the Sirevåg berm breakwater - comparison between model and prototype. Proceedings of the International Coastal Symposium, Høfn, Iceland, June 2005.

[7] Løvås, S.M. (2000): Hydro-physical conditions in kelp forest and the effect on wave damping and dune erosion-a case study on Laminaria hyperborean. Dr.ing. thesis, Department of Structural Engineering, Faculty of Civil and Environmental Engineering, Norwegian University of Science and Technology, Trondheim, Norway.

[8] Knoph (1806): Report on a survey of the Jæren area with respect to the sand drift problems and with a proposal to mitigate the sand drift problems (in Danish, written by hand in Gotish style).

[9] Lindanger, B. (1990): Klepp bygdesoge fram til 1837. Klepp kommune, 1990. (The history of the Klepp municipality up to 1837. Issued by Klepp municipality, a municipality on Jæren).

[10] Floor, J. (around 1900): “Jæderstrand".

[11] Gudmestad, O.T. and Undheim Gudmestad, R. (1998): The Gudmestad Family (Gudmestad slekta. In Norwegian). Publisher Jærprent.

[12] Garborg, A. (1904): Knudahei-brev. (Letters from Knudaheio). Publisher Aschehoug, Kristiania (Oslo).

[13] Hønsi, I. (1989): Storm days at Utsira, Skomvær, Ingøy and Fruholmen. Report of the Norwegian Petroleum Directorate. Report No. OD-89-79.

[14] Sivertsen, K. (1985): Kelp harvesting as a possible cause of increased erosion of the beaches at Jæren. Report 1985:6 of the Nordland College, Bodø, Norway. (In Norwegian).

[15] Berg, B.S. and Munkejord, Aa. (1991): Do the beaches on Jæren disappear? In Yearly report from the Department of the Environment, Governor of the Rogaland County (in Norwegian).

[16] Cowell, P.J., Stive, M.J.F., Roy, P.S., Kaminsky, G.M., Buijsman, M.C., Thom, B.G. and Wright L.D. (2000): Shoreface supply to beaches. Proceedings of the $27^{\text {th }}$ International Conference on Coastal Engineering, July 16-21, Sydney, Australia.

[17] Tørum, A. (1992): Coastal Engineering. Lecture notes, NTNU. (In Norwegian.) 